\title{
Evaluation of Lipid Parameters in Patients Receiving Vitamin B12 Therapy
}

\author{
Vitamin B12 Tedavisi Alanlarda Lipit Parametrelerinin Değerlendirilmesi
}

\author{
(D) Yılmaz Sezgin 1, (D) Sinan Becel2 \\ 1 ístanbul Training and Research Hospital, Clinic of Family Medicine, İstanbul, Turkey \\ 2ijstanbul Bahçelievler State Hospital, Clinic of Emergency Medicine, ìstanbul, Turkey
}

\begin{abstract}
Introduction: We believe that vitamin B12 supplementation may affect serum lipid levels because of its role in fatty acid catabolism and its relationship with serum lipids. In this study, it was investigated whether serum lipid and glucose values were affected in patients receiving vitamin B12 treatment.

Methods: This is a retrospective observational study. In this study, the medical records of patients who applied to the family medicine outpatient clinic were analyzed retrospectively, and serum parameters such as glucose, lipid and vitamin B12 levels and demographic data such as age and gender were evaluated. Twenty-one patients who received treatment due to vitamin B12 deficiency and who had control lipid profile within 6 months, and who did not use any antihiperlipidemics were included in the study.
\end{abstract}

Results: The mean serum cholesterol level was 209.6 \pm 30.1 before treatment and 195.6 \pm 31.7 after treatment $(p=0.002)$. The mean serum triglyceride level was $196.2 \pm 117.8$ before treatment and $142.1 \pm 81.4$ after treatment $(p=0.001)$.

Conclusion: We can conclude that there is a relationship between vitamin B12 and serum lipid parameters, and that serum triglyceride levels are especially affected by vitamin B12 treatment.

Keywords: Fatty acids, lipid parameters, vitamin B12 deficiency

\section{öZ}

Amaç: Yağ asit katabolizmasında rol alması ve serum lipitleri ile ilişkisinin gösterilmiş olması sebebiyle vitamin B12 takviyesinin serum lipit seviyelerini etkileyebileceğini düşünüyoruz. Bu çalışmada, vitamin B12 tedavisi alan hastalarda serum lipit ve glikoz değerlerinin etkilenip etkilenmediği araştırılmıştır.

Yöntemler: Bu çalışma retrospektif gözlemsel bir araştırmadır. $\mathrm{Bu}$ çalışmada, aile hekimliği polikliniğine başvurmuş, hastaların kayıtları geriye dönük incelenmiş, glikoz, lipit ve vitamin B12 gibi serum parametreleri ile yas ve cinsiyet gibi demografik veriler değerlendirilmiștir. Vitamin B12 eksikliği sebebiyle tedavi alan, altı ay içinde tekrar lipit profili baktırmış olan ve herhangi bir antihiperlipidemik kullanmayan 21 hasta çalışmaya dahil edilmiştir.

Bulgular: Serum kolesterol değerlerinin ortalaması tedavi

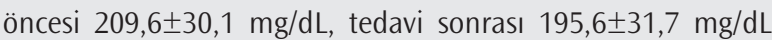
bulundu $(p=0,002)$. Serum trigliserit değerlerinin ortalaması tedavi öncesi 196,2 $\pm 117,8 \mathrm{mg} / \mathrm{dL}$, tedavi sonrası 142,1 $\pm 81,4$ $\mathrm{mg} / \mathrm{dL}$ bulundu $(\mathrm{p}=0,001)$.

Sonuç: Sonuç olarak vitamin B12 ile serum lipit parametreleri arasında bir ilișkinin olduğunu ve özellikle serum trigliserit seviyelerinin vitamin B12 tedavisinden etkilendiğini söyleyebiliriz.

Anahtar Kelimeler: Yağ asitleri, lipit parametreleri, vitamin B12 eksikliği

\section{Introduction}

Vitamin B12 acts as the cofactor of two major enzyme systems in the body. One of these enzyme systems, the methylmalonyl coenzyme A mutase, converts methylmalonyl coenzyme A to succinyl coenzyme A. Methylmalonyl coenzyme A is formed by propionyl coenzyme A carboxylation or valine catabolism, which is formed by isolocine, cholesterol and fatty acid catabolism (1).
Plasma lipids consist of 16\% triacylglycerol (TG), 30\% phospholipid, 14\% cholesterol, 36\% cholesterol esters and 4\% free fatty acids (2). Lipids, such as TG and cholesterol, which are not free in plasma under normal conditions, are found in the form of macromolecules called lipoproteins. According to their electrophoretic activity in ultracentrifuge, lipoproteins are divided into chylomicrons, very low-density (pre-beta) lipoproteins (VLDL), LDL (beta) and high-density (alpha) lipoproteins (HDL) (3). Dyslipidemias, known as lipoprotein metabolism disorders, are classified 


\begin{tabular}{l|l|l|l|l|l|l|l|l}
\hline \multicolumn{2}{l}{ Table 1. Causes of secondary dyslipidemia } \\
\hline Obesity & TG increases, HDL decreases \\
\hline Sedentary life & HDL decreases \\
\hline Diabetes mellitus & TG increases, TC increases \\
\hline Alcohol & TG increases, HDL increases \\
\hline Hypothyroidism & TC increases \\
\hline Hyperthyroidism & TC decreases \\
\hline Nephrotic syndrome & TC increases \\
\hline Chronic renal failure & TG increases, TC increases \\
\hline Cirrhosis & TC decreases \\
\hline Obstructive hepatic impairment & TC increases \\
\hline Malignancy & TC decreases \\
\hline Cushing's disease/Corticosteroid use & TC increases \\
\hline Oral contraceptives & TG increases, TC increases \\
\hline Diuretics & TG increases, TC increases \\
\hline Beta-blockers & TC increases, HDL decreases \\
\hline TG: triacylglycerol; HDL: high-density lipoprotein; TC: total cholesterol. \\
\hline
\end{tabular}

as primary and secondary dyslipidemias according to their etiology. Primary dyslipidemias are characterized more by genetic disorders. The causes of secondary dyslipidemias and related serum lipid changes are shown in Table 1. Fatty acids, cholesterol and cholesterol esters, which are eliminated by the macrophages in the processes following the pathologies occurring in catabolism pathways, cause atherosclerotic plaque formation as a result of accumulation in intimal layers of arteries and lead to cerebral, coronary and peripheral arterial diseases. Dyslipidemia treatment includes lifestyle change, diet, treatment of secondary causes and medical treatment (4).

Vitamin B12 deficiency also increases the risk of developing highmortality clinical conditions such as myocardial infarction and cardiac shock (5). There are studies suggesting that the prevalence of obesity is increased in patients with vitamin B12 deficiency $(6,7)$. It is claimed that vitamin B12 may play a role in the synthesis of an antiprotease, alpha1-antitrypsin (A1AT), and A1AT may be associated with obesity (8). It was suggested that there is a negative correlation between vitamin B12 and serum triglyceride levels and a positive correlation between HDL levels $(9,10)$.

Vitamin B12 being a cofactor of the enzyme involved in fatty acid catabolism, increased risk of obesity and myocardial infarction in vitamin B12 deficiency, and negative correlation between vitamin B12 and triglycerides and positive correlation between $\mathrm{HDL}$ suggest that vitamin B12 supplementation may affect serum lipid levels. In this study, it was investigated whether serum lipid and glucose levels were affected in patients receiving vitamin B12 treatment.

\section{Methods}

\section{Study Design}

This is a retrospective observational study. In this study, the medical records of patients who applied to the family medicine outpatient clinic were analyzed retrospectively, and serum parameters such as glucose, lipid and vitamin B12 levels and demographic data such as age and gender were evaluated. Demographic data such as height, weight, marital status, smoking and alcohol use were not taken into account since they were not included in the patient records. As the study was retrospective, no ethics committee approval was obtained. Vitamin B12 and lipid analyzes were performed to 228 patients who applied to the family medicine outpatient clinic between 28 September 2012 and 17 May 2013. Twenty-one patients who received treatment due to vitamin B12 deficiency and who had control lipid profile within 6 months, and who did not use any antihiperlipidemics were included in the study.

The authors declare that the study was conducted in accordance with the principles of the World Medical Association Declaration of Helsinki "Ethical principles for medical research involving human subjects". Ethical approval was not needed because it was a retrospective study. Consent was not taken from the patients because it was a retrospective study.

\section{Exclusion Criteria}

Patients who received medication due to hyperlipidemia, diabetes, obesity and thyroid disease and who received iron and folate treatment were not included in the study. In addition, since vitamin B12 is stored in the liver and kidney and excreted from the kidney, patients with liver and renal failure were not included in the study. While the exclusion criteria were determined, hospital information system and medulla physician program were used.

\section{Treatment Protocol}

Intramuscular vitamin B12 treatment was 1000 microgram $/ \mathrm{mL} /$ day for 5 days, 1000 microgram $/ \mathrm{mL} /$ week for the following 5 weeks and 1000 microgram $/ \mathrm{mL}$ once a month.

\section{Statistical Analysis}

Statistical Package for the Social Sciences for Windows version 16.0 (SPSS, Chicago, IL, USA) was used to analyze the data. Categorical data were expressed as numbers and percentages. Numerical data were expressed as means and were evaluated by Wilcoxon signed ranks test. The normality of data was evaluated by skewness analysis. In addition, triglyceride values were evaluated by dividing into three subgroups as $\leq 150 \mathrm{mg} / \mathrm{dL}, 151-250 \mathrm{mg} / \mathrm{dL}$ and $\geq 251 \mathrm{mg} / \mathrm{dL}$.

\section{Results}

Twenty-one patients aged 35 to 79 years were included in the study. Fifteen of the patients were female (71\%) and six were male (29\%). The distribution of serum glucose, lipid and vitamin B12 parameters of the patients is shown in Table 2.

Serum cholesterol and triglyceride levels were significantly lower in patients receiving vitamin B12 deficiency treatment than before treatment. The mean serum cholesterol level was $209.6 \pm 30.1 \mathrm{mg} / \mathrm{dL}$ before treatment and $195.6 \pm 31.7 \mathrm{mg} / \mathrm{dL}$ after treatment $(p=0.002)$. The mean serum triglyceride level was $196.2 \pm 117.8 \mathrm{mg} / \mathrm{dL}$ before treatment and $142.1 \pm 81.4 \mathrm{mg} / \mathrm{dL}$ after treatment $(\mathrm{p}=0.001)$. All of the patients who received vitamin $\mathrm{B} 12$ treatment had a decrease in triglyceride 
levels. There was no statistically significant difference between serum glucose, HDL and LDL levels before and after treatment (Table 3).

Serum total cholesterol levels after vitamin B12 treatment were significantly lower in patients with triglyceride levels $\geq 151 \mathrm{mg} / \mathrm{dL}$ before vitamin B12 treatment. There was no statistically significant difference between serum total cholesterol levels before and after vitamin B12 treatment in patients with triglyceride levels $\leq 150 \mathrm{mg} / \mathrm{dL}$ (Table 4). Serum triglyceride levels after vitamin B12 treatment were significantly

\begin{tabular}{l|l|l|l|l|}
$\begin{array}{l}\text { Table 2. Distribution of serum vitamin B12, glucose, lipid } \\
\text { parameters }\end{array}$ & n & Mean \pm SD* $^{*}$ & Minimum & Maximum \\
\hline Age (years) & 21 & $55.38 \pm 14.22$ & 35 & 79 \\
\hline Vitamin B12 (pg/mL) & 21 & $214.14 \pm 73.16$ & 82 & 300 \\
\hline Glucose (mg/dL) & 21 & $89.95 \pm 17.18$ & 61 & 137 \\
\hline Cholesterol (mg/dL) & 21 & $209.57 \pm 30.09$ & 119 & 256 \\
\hline Triglycerides (mg/dL) & 21 & $196.19 \pm 117.79$ & 55 & 476 \\
\hline HDL (mg/dL) & 21 & $47.81 \pm 11.68$ & 32 & 70 \\
\hline LDL (mg/dL) & 21 & $122.10 \pm 25.53$ & 69 & 173 \\
\hline *SD: standard deviation; HDL: high-density lipoprotein; LDL: low-density lipoprotein
\end{tabular}

Table 3. Comparison of serum glucose and lipid parameters before and after treatment

\begin{tabular}{|c|c|c|c|c|c|c|c|}
\hline & Treatment & $\mathrm{n}$ & Mean $\pm S D^{*}$ & $\downarrow$ & $\uparrow$ & $\rightarrow$ & p \\
\hline \multirow{2}{*}{$\begin{array}{l}\text { Glucose } \\
\text { (mg/dL) }\end{array}$} & Before & 21 & $89.95 \pm 17.18$ & \multirow{2}{*}{11} & \multirow{2}{*}{7} & \multirow{2}{*}{3} & \multirow{2}{*}{0.430} \\
\hline & After & 21 & $88.71 \pm 12.51$ & & & & \\
\hline \multirow{2}{*}{$\begin{array}{l}\text { Cholesterol } \\
(\mathrm{mg} / \mathrm{dL})\end{array}$} & Before & 21 & $209.57 \pm 30.09$ & \multirow{2}{*}{17} & \multirow{2}{*}{3} & \multirow{2}{*}{1} & \multirow{2}{*}{$0.002^{* * * *}$} \\
\hline & After & 21 & $195.57 \pm 31.70$ & & & & \\
\hline \multirow{2}{*}{$\begin{array}{l}\text { Triglycerides } \\
\text { (mg/dL) }\end{array}$} & Before & 21 & $196.19 \pm 117.79$ & \multirow{2}{*}{21} & \multirow{2}{*}{0} & \multirow{2}{*}{0} & \multirow{2}{*}{$0.001^{* * * *}$} \\
\hline & After & 21 & $142.14 \pm 81.38$ & & & & \\
\hline \multirow{2}{*}{$\mathrm{HDL}(\mathrm{mg} / \mathrm{dL})$} & Before & 21 & $47.81 \pm 11.68$ & \multirow{2}{*}{12} & \multirow{2}{*}{6} & \multirow{2}{*}{3} & \multirow{2}{*}{0.458} \\
\hline & After & 21 & $54.14 \pm 21.79$ & & & & \\
\hline \multirow{2}{*}{ LDL (mg/dL) } & Before & 21 & $122.10 \pm 25.53$ & \multirow{2}{*}{8} & \multirow{2}{*}{11} & \multirow{2}{*}{2} & \multirow{2}{*}{0.615} \\
\hline & After & 21 & $120.38 \pm 29.21$ & & & & \\
\hline
\end{tabular}

*SD: standard deviation; $\downarrow$ : negative ranks; $\uparrow$ : positive ranks; $\rightarrow$ : ties; HDL: high-density lipoprotein, LDL: low-density lipoprotein. ${ }^{* *}$ Wilcoxon signed ranks test is significant at the 0.05 level (2-tailed); ***Wilcoxon signed ranks test is significant at the 0.01 level (2-tailed) lower in patients with triglyceride levels $\geq 151 \mathrm{mg} / \mathrm{dL}$ and $\leq 150 \mathrm{mg} / \mathrm{dL}$ before vitamin B12 treatment (Table 5).

\section{Discussion}

In our study, serum cholesterol and triglyceride values were lower in patients receiving vitamin B12 deficiency treatment than before treatment. This result suggests that serum lipid parameters, especially triglycerides, are affected by vitamin B12 treatment. There are studies in the literature that support our findings. It has been suggested that hypertriglyceridemia can be effectively reduced by fenofibrate and gemfibrozil treatment, as well as vitamin B6 and vitamin B12 supplement (11). Khaire et al. (12) showed that vitamin B12 and omega-3 supplementation normalize triglyceride levels in rats. In our study, there was no significant difference in serum total cholesterol levels before and after vitamin B12 treatment in patients with triglyceride levels $\leq 150$ $\mathrm{mg} / \mathrm{dL}$. This result shows that vitamin B12 treatment does not affect serum total cholesterol levels in patients with low triglyceride levels. The decrease in serum total cholesterol levels after vitamin B12 treatment in groups with high triglyceride levels suggests that this situation is due to the change in serum triglyceride levels. This finding shows that the relationship between vitamin B12 and lipid parameters can only be related to serum triglyceride levels. Studies in the literature suggest that the relationship between vitamin B12 and serum lipid parameters is more pronounced in obese individuals (13) and in diseases related to increased triglyceride levels such as diabetes $(14,15)$.

Table 4. Comparison of serum total cholesterol levels before and after treatment in subgroups categorized according to triglyceride parameters

\begin{tabular}{|c|c|c|c|c|c|c|c|}
\hline Triglycerides & Treatment & $\mathrm{n}$ & Mean $\pm S D^{*}$ & $\downarrow$ & $\uparrow$ & $\rightarrow$ & p \\
\hline \multirow{2}{*}{$\leq 150 \mathrm{mg} / \mathrm{dL}$} & Before & 8 & $193.75 \pm 32.03$ & \multirow{2}{*}{5} & \multirow{2}{*}{3} & \multirow{2}{*}{0} & \multirow{2}{*}{0.400} \\
\hline & After & 8 & $190.62 \pm 37.15$ & & & & \\
\hline \multirow{2}{*}{$151-250 \mathrm{mg} / \mathrm{dL}$} & Before & 8 & $215.12 \pm 24.32$ & \multirow{2}{*}{7} & \multirow{2}{*}{0} & \multirow{2}{*}{1} & \multirow{2}{*}{$0.018^{* *}$} \\
\hline & After & 8 & $197.75 \pm 30.88$ & & & & \\
\hline \multirow{2}{*}{$\geq 251 \mathrm{mg} / \mathrm{dL}$} & Before & 5 & $226.00 \pm 28.24$ & \multirow{2}{*}{5} & \multirow{2}{*}{0} & \multirow{2}{*}{0} & \multirow{2}{*}{$0.043^{* *}$} \\
\hline & After & 5 & $200.00 \pm 29.32$ & & & & \\
\hline
\end{tabular}

*SD: standard deviation; $\downarrow$ : negative ranks; $\uparrow:$ positive ranks; $\rightarrow$ : Ties; *** wilcoxon signed ranks test is significant at the 0.05 level (2-tailed)

Table 5. Comparison of serum triglyceride levels before and after treatment in subgroups categorized according to triglyceride parameters

\begin{tabular}{|c|c|c|c|c|c|c|}
\hline Triglycerides & Treatment & $\mathbf{n}$ & Mean $\pm S D^{*}$ & Minimum & Maximum & $p$ \\
\hline \multirow{2}{*}{$\leq 150 \mathrm{mg} / \mathrm{dL}$} & Before & 8 & $92.12 \pm 25.61$ & 55 & 126 & \multirow{2}{*}{$0.012^{* * *}$} \\
\hline & After & 8 & $74.50 \pm 20.73$ & 46 & 116 & \\
\hline \multirow{2}{*}{$151-250 \mathrm{mg} / \mathrm{dL}$} & Before & 8 & $190.50 \pm 24.03$ & 160 & 238 & \multirow{2}{*}{$0.012^{* *}$} \\
\hline & After & 8 & $157.00 \pm 31.58$ & 106 & 216 & \\
\hline \multirow{2}{*}{$\geq 251 \mathrm{mg} / \mathrm{dL}$} & Before & 5 & $371.80 \pm 83.35$ & 265 & 476 & \multirow{2}{*}{$0,043^{* *}$} \\
\hline & After & 5 & $226.60 \pm 110.04$ & 112 & 358 & \\
\hline
\end{tabular}


In our study, triglyceride levels were significantly decreased after vitamin B12 treatment in patients with higher triglyceride levels before vitamin B12 treatment. Since our study was retrospective, we do not know whether this decrease was affected by other factors, such as lifestyle changes, which would affect triglyceride levels during vitamin B12 treatment. However, a significant reduction in triglyceride levels was found in patients with triglyceride levels below normal, indicating that vitamin B12 treatment was associated with a decrease in serum triglyceride levels independent of other factors.

The limitations of this study are as follows: retrospective nature of the study, lack of control group, lack of vitamin B12 measurements after treatment, lack of assessment of other factors affecting serum lipid parameters in the treatment process, and post-treatment duration including a long interval of 6 months.

\section{Conclusion}

We can say that there is a relationship between vitamin B12 and serum lipid parameters and that especially serum triglyceride levels are affected by vitamin B12 treatment. However, we think that more comprehensive studies should be done on this subject.

Ethics Committee Approval: The authors declare that the study was conducted in accordance with the principles of the World Medical Association Declaration of Helsinki "Ethical principles for medical research involving human subjects”. Ethical approval was not needed because it was a retrospective study.

Informed Consent: Consent was not taken from the patients because it was a retrospective study.

Peer-review: External and internal peer-reviewed.

Author Contributions: Concept - Y.S.; Design - Y.S.; Supervision - Y.S., S.B.; Resources - Y.S.; Data Collection and/or Processing - Y.S.; Analysis and/or Interpretation - Y.S.; Literature Search - Y.S.; Writing Manuscript - Y.S.; Critical Review - S.B.

Conflict of Interest: No conflict of interest was declared by the authors.

Financial Disclosure: The authors declared that this study received no financial support.

\section{References}

1. Murray RK, Bender DA, Botham KM, Kennelly PJ, Rodwell VW, Weil PA. Micronutrients: Vitamins \& Minerals. In Harper's Illustrated Biochemistry, $28^{\text {th }}$ ed. The McGraw-Hill Companies; 2009. pp. 467-81.

2. Murray RK, Bender DA, Botham KM, Kennelly PJ, Rodwell VW, Weil PA. Lipid Transport \& Storage. In Harper's illustrated biochemistry, $28^{\text {th }}$ ed. The McGraw-Hill Companies; 2009. pp. 212-23.

3. Beers MH, Berkow R. Hyperlipidemia. In the merck manual of diagnosis and therapy, $17^{\text {th }}$ ed. Merck and Co. Inc; 1999: 200-11.

4. Sezgin Y, Özçakar N. Management of dyslipidemia. Turkish Family Physician 2011; 2: 30-5.

5. Oh RC, Brown DL. Vitamin B12 deficiency. Am Fam Physician. 2003; 67: 993-4.

6. Pinhas-Hamiel O, Doron-Panush N, Reichman B, Nitzan-Kaluski D, Shalitin S, Geva-Lerner L. Obese children and adolescents, a risk group for low vitamin B12 concentration. Arch Pediatr Adolesc Med 2006; 160: 933-6.

7. Karatela RA, Sainani GS. Plasma homocysteine in obese, overweight and normal weight hypertensives and normotensives. Indian Heart J 2009; 61: 156-9.

8. Sezgin Y. Kartal M, Güldal AD. A comparison of serum alpha-1-antitrypsin and vitamin B12 levels in patients with vitamin B12 deficiency. J Clin Anal Med 2018; 9: 192-4.

9. Sezgin Y, Becel S. Comparison of serum lipid parameters and serum vitamin B12 levels. J Clin Anal Med 2018.

10. Saraswathy KN, Joshi S, Yadav S, Garg PR. Metabolic distress in lipid \& one carbon metabolic pathway through low vitamin B-12: a population based study from North India. Lipids Health Dis 2018; 17: 96.

11. Dierkes J, Westphal S, Luley C. The effect of fibrates and other lipid-lowering drugs on plasma homocysteine levels. Expert Opin Drug Saf 2004; 3: 101-11.

12. Khaire A, Rathod R, Kale A, Joshi S. Vitamin B12 and omega-3 fatty acids together regulate lipid metabolism in Wistar rats. Prostaglandins Leukot Essent Fatty Acids 2015; 99: 7-17.

13. Abacı A, Akelma AZ, Özdemir O, Hızlı \$̧, Razi CH, Akın KO. Relation of total homocysteine level with metabolic and anthropometric variables in obese children and adolescents. Turk J Med Sci 2012; 42: 69-76.

14. Adaikalakoteswari A, Jayashri R, Sukumar N, Venkataraman H, Pradeepa R, Gokulakrishnan K, et al. Vitamin B12 deficiency is associated with adverse lipid profile in Europeans and Indians with type 2 diabetes. Cardiovasc Diabetol 2014; 13: 129.

15. Ahmed S, Rohman SM. Study of serum Vitamin B12 and its correlation with Lipid profile in type 2 diabetes mellitus. Indian Journal of Basic and Applied Medical Research 2016; 5: 92-103. 